\title{
RELATIONSHIP BETWEEN ANTICARDIOLIPIN AND MULTIPLE SCLEROSIS PATIENTS
}

\author{
Haider J. Mohammad*, Rana S. Aboudi** and May K. Ismaeel** \\ * College of Sciences Department of Biology, Al-Mustansiriya University. \\ **College of Sciences Department of Biology, Baghdad University.
}

\begin{abstract}
The presence of anticardiolipin in serum of multiple sclerosis patients has been reported frequently but no clear relationship between anticardiolipin and the clinical neuroimaging features of multiple sclerosis. To analyze the possible role of anticardiolipin antibody in the pathogenesis of multiple sclerosis. We investigated(22) patients with multiple sclerosis of ages 25-45 years. The patients were also compared with(20) healthy individuals.

We found there was a highly significant elevation in the concentration of $\operatorname{IgG}$ and IgM anticardiolipin antibody in patient with multiple sclerosis than in control group $\mathrm{P}<0.001$. The prevalence of $\mathrm{IgG}$ and IgM anticardiolipin antibody was $36.4 \%$ and $27.3 \%$ respectively.

There was a highly significant difference between study groups. The findings of this preliminary study show that increased levels of anticardiolipin $\operatorname{IgG}$ and $\operatorname{IgM}$ associated with exacerbations of multiple sclerosis.

The significance of this association in the pathogenesis of multiple sclerosis remains unknown.
\end{abstract}

\section{Introduction}

Multiple sclerosis (MS), also known as disseminated sclerosis or encephalomyelitis disseminate is an autoimmune condition in which the immune system attacks the central nervous system (CNS), the brain and spinal cord, lead to demyelination [1,2,3]. Disease onset usually occurs in young adult, it is more common in women and has a prevalence that ranges between 2 and 150 per 100000 depending on the country or specific population and this disease was first described in 1835 by Jean Martin Char cot $[4,5,6]$.

In multiple sclerosis (MS) case control studies have shown that anticardiolipin antibodies (ACL $\mathrm{Ab}$ ) are more frequent than in the general population $[7,8,9]$.

Patients with ACL Ab (antibody directed against cardiolipin), these are one of the antiphospholipid antibody syndrome (APS) [10].

Whereas cardiolipin (biphosphotidyl glycerol) is an important component of the inner mitochondrial membrane where it constitutes about $20 \%$ of the total lipid and it is typically present in metabolically active cells of the heart and skeletal muscle in the membrane of their mitochondria [11].
Multiple sclerosis (MS) and antiphospholipid antibody have many things in common, MS is probably an autoimmune disease and anticardiolipin antibody is seen in some patients especially of neuromyelitic type [12].

In addition bright T2_Imaging foci are occasionally detected in brain MRI (Magnetic Resonance Imaging) of patients with antiphospholipid antibody syndrome (APS) [13]. For unequivocal of antiphospholipid syndrome a patients have both a clinical event (thrombosis and pregnancy loss), antiphospholipid antibody but not the syndrome, can be induced by drugs or infections [14]. The purpose of this study was to determine whether patients with (MS) are positive for ACL.

\section{Patients and Methods}

The study included (22) patients with multiple sclerosis of ages 25-45 years and (20) healthy blood donors taken as a healthy control group.

$\operatorname{IgG}$ and $\operatorname{IgM}$ anticardiolipin antibodies were measured in both serum samples by using Enzyme-Linked Immunosorbent Assay (ELISA). This was performed as described in the leaflet of the kit (AESKULISA, Germany). 


\section{Statistical Analysis}

Comparison of paired data from the three groups of subjects was done using T-test ( $\mathrm{t}$ ), while correlations between groups were analyzed using Pearson correlation coefficient(r) formula.

Statistical tables including observed frequencies with their percentage.

SPSS and Microsoft Excel Programs were used for T-test and correlation coefficient calculations respectively [15].

\section{Results}

The levels of ACL in patient with multiple sclerosis and controls are reported in Tables \& Fig. (1).

There was a highly significant elevation in IgM and IgG ACL concentration in patient with multiple sclerosis than in negative and control groups $(\mathrm{P}<0.001)$.

The prevalence of $\operatorname{IgM}$ and $\operatorname{IgG}$ was $36.4 \%$ (8 of 22) and $27.3 \%$ (6 of 22) respectively. There was highly significant difference between study groups.

Table (1)

Anti-cardiolopin Ab. (IgG) in sera of multiple sclerosis patients.

\begin{tabular}{|c|c|c|c|c|c|}
\hline \multirow{2}{*}{ Diseases } & \multirow{2}{*}{$\begin{array}{c}\text { Anti- } \\
\text { Cardiolopin } \\
\text { Ab. (IgG) }\end{array}$} & \multirow{2}{*}{ No. } & \multirow{2}{*}{$\%$} & \multicolumn{2}{|c|}{ Chi-square $\left(\chi^{2}\right)$} \\
\hline & & & & P-value & Sig. \\
\hline \multirow{2}{*}{ MS } & Positive & 6 & 27.3 & \multirow{2}{*}{0.033} & \multirow{2}{*}{$\begin{array}{c}\text { Sig. } \\
(\mathbf{P}<0.05)\end{array}$} \\
\hline & Negative & 16 & 72.7 & & \\
\hline
\end{tabular}

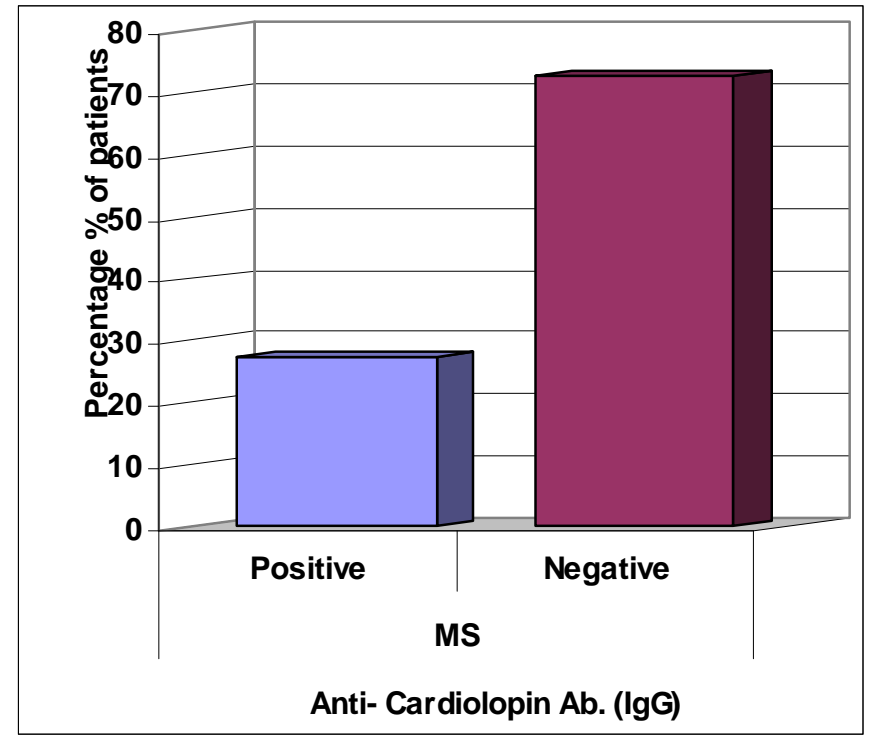

Fig. (1): Anti-cardiolopin Ab.(IgG) in sera of multiple sclerosis patients. 
Table (2)

Anti-cardiolopin Ab.(IgM) in sera of multiple sclerosis patients.

\begin{tabular}{|c||c|c|c||c|c||}
\hline \multirow{2}{*}{ Diseases } & $\begin{array}{c}\text { Anti- } \\
\text { Cardiolopin } \\
\text { Ab. (IgM) }\end{array}$ & No. & $\%$ & \multicolumn{2}{|c|}{ Chi-square $\left(\chi^{2}\right)$} \\
& Positive & 8 & 36.4 & P-value & Sig. \\
\cline { 2 - 4 } MS & Negative & 14 & 63.6 & 0.201 & $\begin{array}{c}\text { Non Sig. } \\
(\text { P>0.05) }\end{array}$ \\
\hline
\end{tabular}

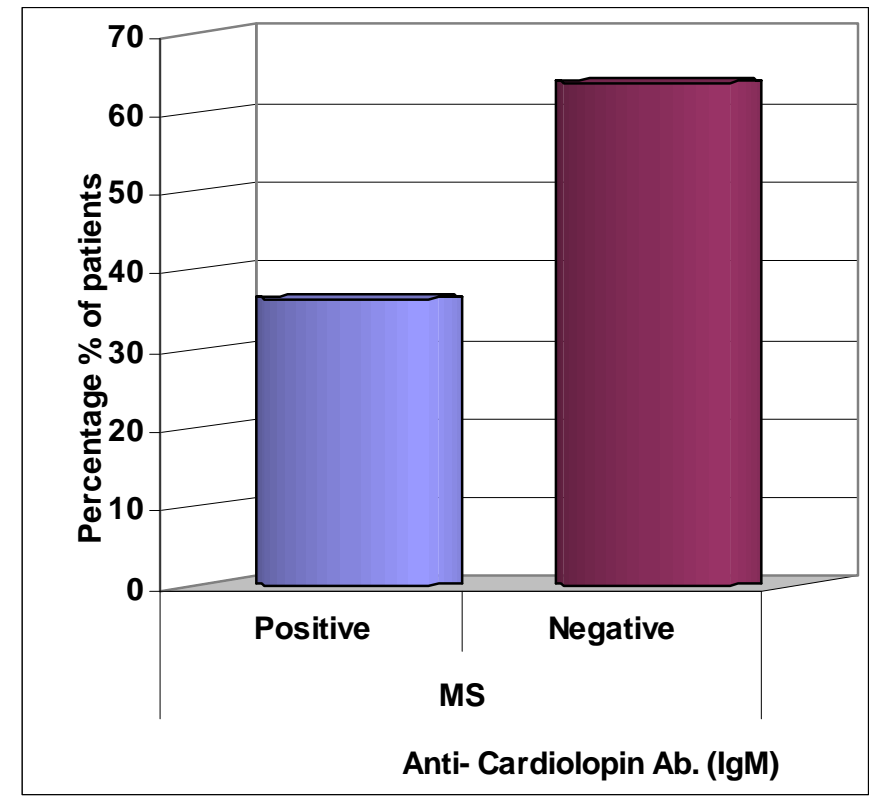

Fig. (2) : Anti-cardiolopin Ab.(IgM) in sera of multiple sclerosis patients.

Table (3)

Mean distribution of anti-CLP Ab-IgG (GPL/ml) level among studied group

(Control \& multiple sclerosis patients).

\begin{tabular}{|c|c|c|c|c|c|c|c|c|c|}
\hline \multirow{2}{*}{\multicolumn{2}{|c|}{ Studied group }} & \multirow[t]{2}{*}{$\mathbf{N}$} & \multirow[t]{2}{*}{ Mean } & \multirow[t]{2}{*}{ SD } & \multirow{2}{*}{$\begin{array}{l}\text { Std. } \\
\text { Error }\end{array}$} & \multirow[t]{2}{*}{ Mini. } & \multirow[t]{2}{*}{ Maxi. } & \multicolumn{2}{|c|}{$\begin{array}{l}\text { Student test } \\
\text { (t-test) }\end{array}$} \\
\hline & & & & & & & & P-value & Sig. \\
\hline \multicolumn{2}{|c|}{ Control } & 20 & 8.65 & 2.37 & 0.53 & 4 & 13 & - & - \\
\hline \multirow{2}{*}{$\underset{\text { (IgG) }}{\text { Anti-CLP Ab. }}$} & Positive & 6 & 29.83 & 8.04 & 3.28 & 19 & 43 & 0.00 & HS \\
\hline & Negative & 16 & 7.75 & 2.05 & 0.51 & 5 & 12 & 0.455 & NS \\
\hline \multicolumn{2}{|c|}{ Total } & 42 & \multicolumn{5}{|c|}{ Positive Vs Negative } & 0.00 & HS \\
\hline
\end{tabular}




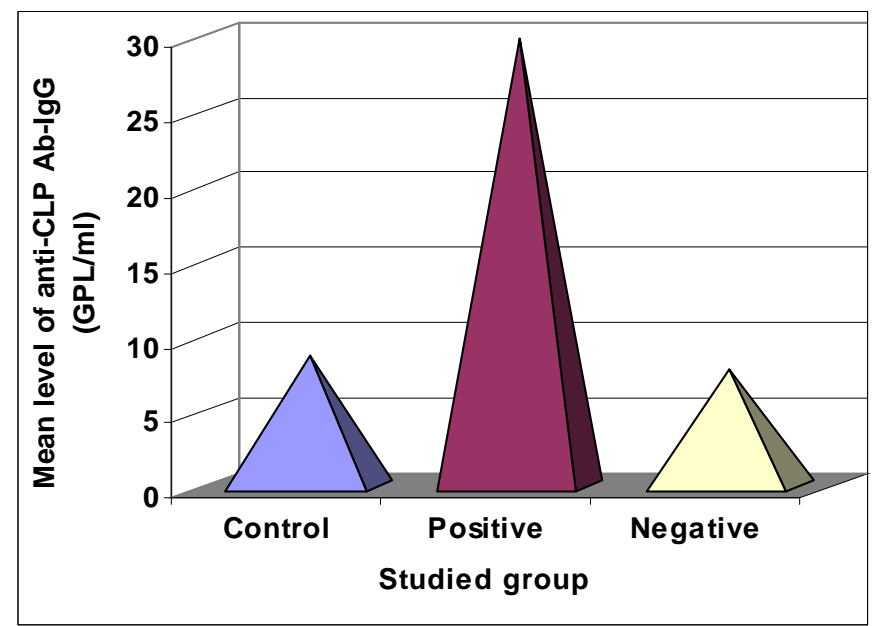

Fig. (3) : Mean distribution of anti-CLP Ab-IgG (GPL/ml) level among studied group (Control \& multiple sclerosis patients).

Table (4)

Mean distribution of anti-CLP Ab-IgM (MPL/ml) level among studied group

(Control \& multiple sclerosis patients).

\begin{tabular}{|c|c|c|c|c|c|c|c|c|c|}
\hline \multirow{2}{*}{\multicolumn{2}{|c|}{ Studied group }} & \multirow[t]{2}{*}{$\mathbf{N}$} & \multirow[t]{2}{*}{ Mean } & \multirow[t]{2}{*}{ SD } & \multirow{2}{*}{$\begin{array}{l}\text { Std. } \\
\text { Error }\end{array}$} & \multirow[t]{2}{*}{ Mini. } & \multirow{2}{*}{ Maxi. } & \multicolumn{2}{|c|}{$\begin{array}{l}\text { Student test } \\
\quad \text { (t-test) }\end{array}$} \\
\hline & & & & & & & & P-value & Sig. \\
\hline \multicolumn{2}{|c|}{ Control } & 20 & 9.1 & 2.13 & 0.48 & 6 & 13 & - & - \\
\hline \multirow{2}{*}{$\begin{array}{l}\text { Anti-CLP Ab. } \\
\text { (IgM) }\end{array}$} & Positive & 8 & 35.75 & 20.76 & 7.34 & 19 & 62 & 0.00 & HS \\
\hline & Negative & 14 & 7.21 & 1.58 & 0.42 & 5 & 10 & 0.571 & NS \\
\hline \multicolumn{2}{|c|}{ Total } & 42 & \multicolumn{5}{|c|}{ Positive Vs Negative } & 0.00 & HS \\
\hline
\end{tabular}

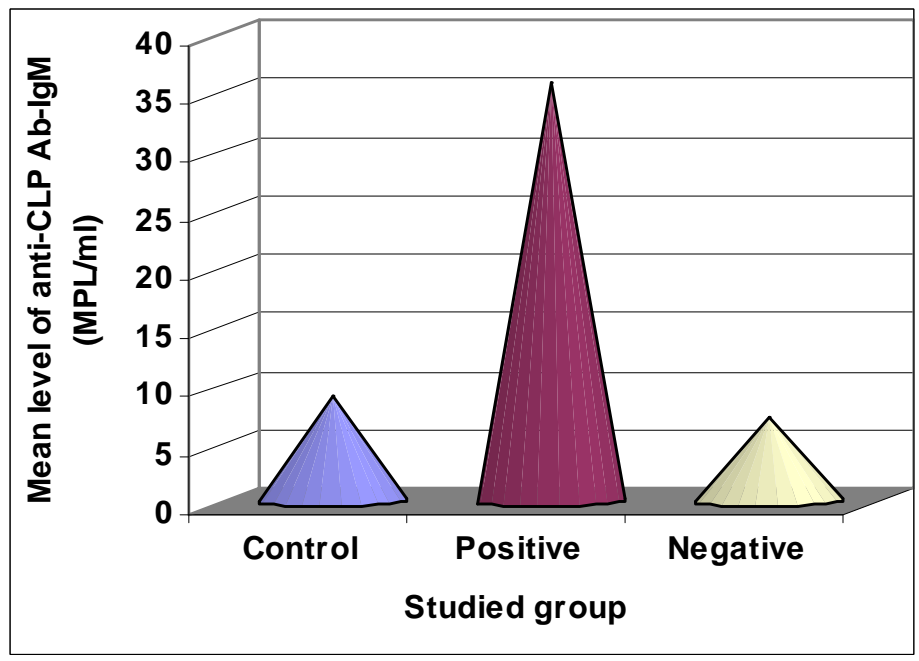

Fig. (4): Mean distribution of anti-CLP Ab-IgM (MPL/ml) level among studied group (Control \& multiple sclerosis patients). 


\section{Discussion}

The central finding of this research as a close association between ACL and certain clinical and neuroradiologic features of (MS). The previous studies failed to detect this association because they did not distinguish clinical states of the patients or used method unable to make this discrimination.

There are few reports on ACL $\mathrm{Ab}$ in association with (MS). In one study, the frequency of ACL $\mathrm{Ab}$ in patient with (MS) was $88 \%$, in another report found 14 of 32 positive for IgM but only 3 of 32 positive for IgG [16].

In another study, ACL Ab positively was found in 29 patients (32.6\%) 15 of the $\mathrm{IgG}$ and 4 of the $\operatorname{IgM}$ ecotype, through a retrospective study, the investigators shown that ACL Ab are more frequent than in the general population and that ACL Ab positively may be associated with specific clinical characteristics [7].

The greater frequency of other Abs in ACL $\mathrm{Ab}$ positive patient suggests that they only reflect a more general autoimmune activation in (MS) [16].

The clinical significance of the findings of this study is unknown, however, there are two broad possibilities: first, that ACL Ab in (MS) may contribute causally to the disease pathogenesis or that ACL are secondary epiphenomenal with no role in promotion of the inflammatory cascade of (MS) [17, 18].

Many antiphospholipid antibodies (APLA) are now known, and certainly many more exist. Therefore it is possible that APLA in (MS) are directed against some specific Ag that could be involved, for example in BBB $[19,20]$.

A number of available reports document cross-reaction of some ACL with endothelial cells and platelets. [21]

Raising the possibility that the rise of specific types of APLA in the (MS) subjects could trigger exacerbation by further compromise of the BBB. We have shown complex effects of plasma from (MS) patients on brain micro vascular endothelial cell in tissue cellular. [22,23]

It should be stressed that our assay against the four pure phospholipids will detect any PLbinding protein, not necessarily those thus for identified as APLA. It is possible that we are checking Ags specifically involved in compromise of the $\mathrm{BBB}$, possibly responsible for the endothelial activation that use reported in exacerbation of (MS) [24].

\section{Conclusions}

The findings of this preliminary study demonstrate presence of $\operatorname{IgG}$ and IgM APLA during exacerbations of (MS). Currently, the significance of these auto antibodies in pathogenesis of (MS) remains unknown.

Longitudinal studies to measure both $\mathrm{IgG}$ and IgM classes of APLA in larger cohorts of patients with relapsing-remitting (MS) are necessary to establish the significance of these auto antibodies and assess their pattern of expression before and after treatment with disease modifying agents.

\section{References}

[1] D, Baker and D.J. Han key, "Gene therapy in autoimmune, demyelization disease of the central nervous system". Gene Ther, 10 (2003), PP.844-853.

[2] C.J. Bidot.; L.L.; Horstman, J.Y.; Wenche, , J.; Joaquin , J.R Bidot.; S.A.; Yeon, Steven, J.; Eduardo, Toledo, C.; R.Y Kellet and A. Minagar, Clinical and neuroimaging correlates of antiphospholipid antibodies in multiple sclerosis : a preliminary study. BMC. Neurology, 7, (2007), PP. 36.

[3] CG Goetz, ed. Multiple sclerosis. In: Textbook of clinical neurology. $2^{\text {nd }}$ ed. Saunders Philadelphia, PA (:2003).

[4] A.Chang, W.W Tourtellotte, R. Rudick,; and B.D Trapp,. "Premyclinating digodehydrocytes in chronic lesions of multiple sclerosis" Neur. Engl. J. Med. 346, (2002), PP. 165-173.

[5] J.H., Noseworthy, C, Lucchinetti, M, Rodriguez, and B.G Weinshenker, Multiple sclerosis (Review), Neur. Engl. J. Med, 343,(2000),PP. 958-952.

[6] W. Stillwell and R.S. Wassall,. Docosahexaenoic acid: Membrane properties of a unique fatty acid, Chemistry and Physics of lipids, 126, (2003), PP. 1-27. 
[7] O.; Heinz let, B.; Weill, C.; Cohanel, V.; Sazdovitch, S; Caillat-Zucman, E.; TournierLasserve, and Enrolled, Anticardiolipin antibodies in patients with multiple sclerosis. Don't represent a subgroup of patients according to clinical. Familial and biological characteristics. J. Neurology Neurosurgery and psychiatry. 72, (2002), PP. 647-649.

[8] V.; Yi, F Roussel.; M.O.; Jauberteau C; Couderq, C.; Lacombe, V.; Michelet, R.; Gill, P.; Couratier, J.M.; Vallat, and J.L. Priedhome, Prevalence and clinical significance of anti-phospholipids antibodies in multiple sclerosis : a study of 89 patients. J. Autoimmune, (2000), PP. 259-265.

[9] L.R. Samaritan, Antiphospholipid syndrome, Review. J. South. Med, 98, (2005), PP. 617625.

[10] HP.McNeil, Antiphospholilpid antibodies are directed against a complex antigen that includes a lipid - binding inhibitor of coagulation: beta 2 - glycoprotein 1 (apoliproteinH), Proc. Natio. Acad. Sci. U.S.A. 87,11, (1990), PP.4120 - 4.

[11] Krebs, Hauser and Carofoil, Asymmetric distribution of phospholipids in the inner membranes of Beef heart mitochondria. J.B.Ch. 254, .12, (1979), PP. 5308-5316.

[12]Z. Habebaghahi, M.D, Anticardiolin Antibody in Patients with Multiple Sclerosis. S.M.J. of SUMS. (2000).

[13] D. Karusis, RR. Leker, A. Asheranazi, O.Abramsky Subgroup of multiple sclerosis patients with anticardiolipin antibody and unusual clinical manifestations: Do they represent an new nosological entity? Annals of neurology. 44, (1998), PP. 629-634.

[14] MD Lockshin, Antiphospholipid antibody syndrome. Kelley's book of Rheumatology, (2001), pp. 1145-1152.

[15]DE. Sorlei, Medical biostatistics and epidemiology examination and board review. First ed. Norwalk, Connecticut, Appleton and Lange, (1995), PP. 47-88.

[16] Y.; Sugiyama and Y. Yamamoto, Characterization of serum anti-phospholipids antibodies in patients with multiple sclerosis, Tohoky, J.E. XP. Med. 178, (1996), PP.203215.
[17] S.L.; Hauser and J.R Oksenberg, The neurobiology of multiple sclerosis. Genes, Inflammat. And Neurodegeneration, Neuron, 52, (2006), PP. 61-76.

[18]E.M.; Forman M.K.; Rack and C.S.Raine, Multiple sclerosis: The plaque and its pathogenesis. Neur. Engl. J. Med. 354, (2006), PP. 942-955.

[19] R.; Simanlov Lo, S.K.; A.; Gharravi L.R.; Samaritan, , J.E Salmon and R.L. Silversten, Antiphospholipid antibodies activate vascular endothelial cells. Lupus. 5, (1996), PP. 440-441.

[20] S.S.; Pierangeli R.G.; Espanola, D.E.; Farrar and E.N. Harris, Activation of endothelial cell nuclear factor $\mathrm{KB}$ by antiphospholipid antibodies. Blood. 98,(2001),PP. 56b.

[21]P.L.; Meroni, E.; C.; RaschiTestoni, A.Tincani, and G.Balestrieri, Antiphospholipid antibodies and the endothelium. Rheum. Dis. Clin. North. Am. 27, (2001), PP. 587-602.

[22] J.Y.W.; Minagar J.J.; Jimenez, W.A.; Sheremata, L.; Mauro, L.L.; Horseman, C.J.; Bidot and Y.S. Ahn, Endothelial micro particles (EMP) bind to monocytes to activate and enhance transmigration: Elevated circulating EMP-monocyte conjugates in multiple sclerosis. Frontiers Bio. Sci., 9, (2004), PP. 3132-3144.

[23] J.J.; Jimenez Jy, W.; Mauro, L.L.; Horstman, Abu, E.R.; Y.S.; Ahn and A.Minagar, Elevated endothelial micro particle-monocyte complex included by multiple sclerosis plasma and the inhibitory effects of interferon-beta $1 b$ on release of endothelial micro particles, formation and Tran endothelial migration of monocyteendothelial micro particle complexes. Multiple Sclerosis. 11, (2008), PP. 310-315.

[24] A.; Minagar, Jy, W.; J.J.; Jimenez, L.M.; Mauro, L.L.; Horstman, Y.S.; Abu, and W.A. Sheremata, Elevated plasma endothelial micro particles in multiple sclerosis, Neurology, 56,(2001), PP. 13191324. 


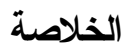

أن ظهور أضداد شحميات القلب فـــي مرضــى تصــلب

الأعصاب المنتشر قد نم اثباته ، لكن لا نوجد علاقة و اضحة

بين وجود هذه الأضداد و هذا المرض بحيث يمكن ملاحظتها.

ولتحليل الوظيفة المحتملة لهذه الأضداد في امر اضية تصــلب الب فهرد

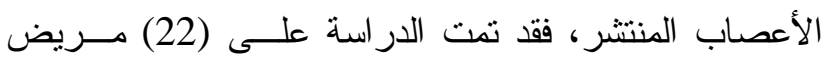

مصاب بهذا المرض وبأعمار تتز اوح بين 25-45 سنة مــع

إجر اء مقارنة بين هؤلاء المرضى مع (20) شخص من النوع

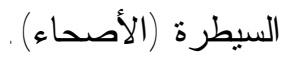

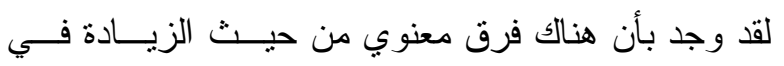

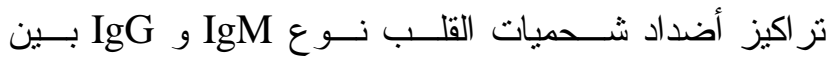

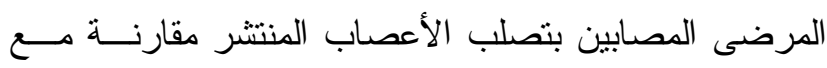

السيطرة (الأصحاء) (P>0.001) . وقاب كانت نسبة الزيـادة

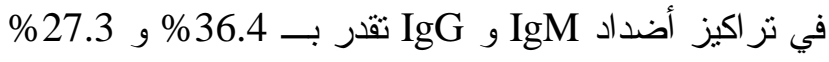

على التو الي. وقد كانت هناك فروق معنوية عالية بين مجاميع

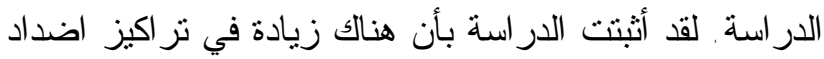
شحميات القلب نوع IgG و IgM مقترنة مع الاصابة بمرض

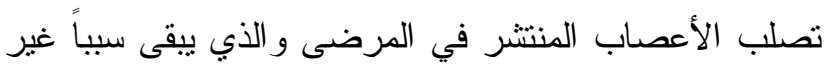
معروف في هذه الامر اضية. 